ELORE (ISSN 1456-3010), vol. $12-1 / 2005$.

Julkaisija: Suomen Kansantietouden Tutkijain Seura ry. Taitto: Jukka Talve.

[http://cc.joensuu.fi/ /oristi/1_05/fin1_05.pdf]

\title{
PÄÄKIRJOITUS:
}

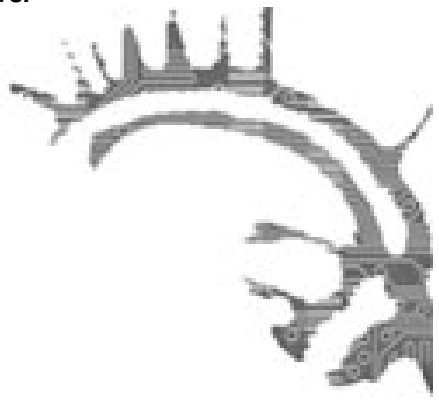

\section{KISÄLLINNÄYTE JA OPEN ACCESS}

\section{Outi Fingerroos}

Käsillä - tai näppäimissä - oleva Elore on ensimmäinen, jota olen tehnyt päätoimittajana. Astuin Eloren toimittajaremmiin mukaan vuonna 2002, silloin vielä väitöskirjaa valmistelevana apurahatutkijana. Katunut en ole kertaakaan, sillä toimitustyö on ollut työteliäisyydestään huolimatta kovasti opettavaista. Kulttuurien tutkijana olen aina ollut suulas kameleontti liikkuessani uskontotieteen, folkloristiikan, kansatieteen, humanistisen maantieteen ja eri historioiden rajoilla, joten toimituskuntaan pääseminen oli minusta, risteilijästä, tietenkin houkuttelevaa. Ilokseni Eloren toimituskunnasta löytyi oma oppitytön ja sittemmin ihan osaavan vakiotoimittajan paikka. Päätoimittajaksi siirtyminen olikin viime kevään väitöksen jälkeen suorastaan luontevaa. Uuteen tehtävään sopeutumista on edesauttanut se, että Sinikka Vakimo teki omalla kaudellaan vakuuttavaa jälkeä. Pöytä oli valmiiksi katettuna odottamassa minua ja luotsaamaani toimituskuntaa. Eloren tekeminen on iloista tiimityötä, mitä lähtökohtaa pidän oman päätoimittajakauteni johtotähtenä.

Syksyllä 2004 teimme toimituskunnassa merkittävän ratkaisun: päätimme jättää html-koodauksen. Syitä muutokselle oli oikeastaan kaksi. Ensinnäkin keskustelu Eloren julkaisutukiongelmista oli akuutti, sillä Suomen Akatemian kielteinen asenne open access -lehteämme kohtaan pakotti miettimään mahdollisuutta toimittaa postilaatikkoon kannettava, reilun parinkymmenen euron hintainen paperi-Elore. Tätä ajatusta ei ole vieläkään haudattu - huolimatta siitä, että open access puhuttaa entistä enemmän ja Elore on vapaasti saatavien julkaisujen pioneereja Suomessa. Toiseksi mietimme lehden teknistä toteutusta ja ennakoimme tulevaisuutta. Uusien kotisivujen rakentaminen ja html-taitosta luopuminen näyttivät "tässä hetkessä" järkevimmiltä ratkaisuilta - etenkin kun toimituskuntaan liittyi alkuvuodesta teknisesti taitava tutkija Jukka Talve.

Ulkoisesti Elore on saanut uuden ilmeen. Jukka Talven suunnittelemat kotisivut on rakennettu harkiten: niin, että ne ovat teknisesti toimivat, helpot käyttää ja tyyliltään huolitellun asialliset. Siksi sivustolta on turha etsiä multimediaefektejä tai pitkiä linkkilistoja. Kotisivut palvelevat perinteentutkimuksesta ja kulttuurien tutkimuksesta kiinnostuneita tiedonjanoisia internet-ajan ihmisiä. Sivuilta löytää 


\section{OUtI FingerRoOS}

kätevästi perustiedot lehdestä, kirjoitettavien tekstien ohjeet, toimituskunnan yhteystiedot ja aikaisempien numeroiden arkiston. Sivuilta pääsee myös julkaisijan, Suomen Kansantietouden Tukijain Seura ry:n kotisivuille. Kaikki julkaistavat tekstit ovat nyt pdf-muodossa. Taitto on niin ikään Jukka Talven käsialaa. Tiedostoja on rakennettu tietokoneita ja internetyhteyksiä silmällä pitäen. Kaikkein vanhimmilla modeemikoneilla pdf-tiedostojen lataaminen ja lukeminen voi olla hidasta, mutta keskiverto kokoonpanolla homma luonnistuu. Elore elää internet-ajassa, joten oletuksena on, että kotikoneetkin uudistuvat. Sivustojen tekninen toteutus ja ylläpito kuuluvat siis Jukka Talvelle, mutta Eloren kotisivutila ja seuran kotipaikka löytyvät edelleen Jyrki Pöysän isännöimästä Joensuusta.

Toimituskunnassa on niin ikään tapahtunut muutoksia, sillä mukana on useita uusia kasvoja: Helena Saarikoski Helsingistä, Tarja Kupiainen Joensuusta, Maarit Knuuttila Jyväskylästä sekä Taina Ukkonen ja Jukka Talve Turusta. Teimme syksyllä muutamia toimituksellisia uudelleenjärjestelyjä, sillä päätoimittajan taakka on paisunut viimeisten vuosien aikana yhdelle ihmiselle turhan raskaaksi. Nyt lehdellä on omat vastuutoimittajansa: Elina Makkonen ja Helena Saarikoski työstävät kirja-arvioita, ja Tarja Kupiainen ja Niina Hämäläinen ahkeroivat ajankohtaistapalstalla. Ratkaisu on toiminut erinomaisesti, sillä päätoimittaja voi nyt muun toimituskunnan avustuksella keskittyä katsausten ja referoitavien artikkelien toimittamiseen. Lehtemme tekeekin yksittäisten tekstien eteen huomattavan paljon töitä, joten mikään helppo julkaisuväylä Elore ei ole. Etenkin nuorille ja kokemattomille kirjoittajille pyrimme antamaan mahdollisimman laadukasta palautetta keskeneräisistäkin töistä.

Sinikka Vakimo viittasi viimeisessä pääkirjoituksessaan open access eli vapaasti julkaistavien tiedelehtien ongelmiin rahoituskentällä. Sen jälkeen keskustelua on käyty laajemminkin - onhan vapaasti saatavien tutkimusten määrä nykyisellään jo lähes 20 prosentin suuruusluokkaa ja Eloren lisäksi kymmenkunta muuta tiedejulkaisua on avoimesti verkossa luettavissa. Itse asiassa tutkimusten avoin saatavuus on pääministeri Vanhasenkin mielestä ideaali, kuten hän muotoili Tieteen päivillä: "Tavoitteena on, että tieteelliset julkaisut olisivat tutkijoiden ja kansalaisten vapaasti saatavilla verkossa." Tämä kuuluu olevan hallituksen tietoyhteiskuntanäkökulmankin kannalta "erityisen tärkeää". (Ks. Kuusela 2005.) Puheet ovat kuitenkin puheita, sillä ainakin Elorea on rangaistu vapaasta saatavuudesta, yli kymmenen vuoden talkootyöstä ja taloudellisesti niukasta elosta.

Kauniisti ilmaisten Eloren kaltaisilta open access -lehdiltä siis puuttuvat todelliset julkaisun kannustimet. Ilmeisesti olemme vähän hassua porukkaa ja idealisteja. Kimmo Kuusela kirjoitti maaliskuun 2005 Acatiimissa terävästi: "Suomen opetusministeriön viime syksynä asettaman arvovaltaisen työryhmän tehtävänä oli laatia suositukset avoimen tieteellisen julkaisutoiminnan edistämiseksi Suomessa. Kuten muualla maailmassa annetut vastaavanlaiset open access suositukset, myöskään nämä Suomen vastikään julkaistut ehdotukset eivät sisällä varsinaisia keppitai porkkana-tyypin kannusteita vaan pitäytyvät maltillisen vapaaehtoisuuden periaatteessa." Eloren toimitustyö on sen verran vaativaa työtä, että olisi kohtuullista saada seuran ulkopuolelta edes muutama lappu kahisevaa riihikuivaa. Toimitukselta 
alkaa maltti loppua. Päätoimittajana häärivä orjapiiskuri hätyyttelee taittajaa, jonka hermoille maineikkaan porkkanan järsiminen käy varsinkin niinä päivinä, kun paperilehdissä häärivät toimitussihteerit vievät puolisonsa viinibaariin. Avoimeen julkaisemiseen liittyvät kummallisuudet ovatkin asia, josta lehtemme toimituskunta keskustelee vakavasti toukokuisessa palaverissa. On näkyvän julkilausuman aika.

Kisällinnäytteeksi ristittävän Eloren 1/2005 teemana on kuolema. Teemanumeron ovat toimittaneet toimituskunnan kuolema-tutkijat Kaarina Koski ja Outi Fingerroos. Kokoelman aloittaa pitkän linjan kuolema-asiantuntijan, professori Juha Pentikäisen kolumni. Salme Korhonen kokosi pyynnöstämme laajan bibliografian Kuolema ja kulttuurien tutkimus, joka toimii täydennyksenä vuonna 1990 ilmestyneelle bibliografialle Kuolema Suomen perinnetieteellisessä kirjallisundessa vuoteen 1989 (SKS). Referoituja artikkeleita teemanumerossa on kuusi kappaletta, joissa kuolemaa lähestytään yhtä hyvin pohjalaisen puukon kuin itkujen ja eutanasian näkökulmista. Teeman lisäksi uunituore numero sisältää joukon kiintoisia kirja-arvioita ja ajankohtaiskeskusteluja.

Lehdellemme tarjottavien tekstien määrä on koko ajan kasvanut. Se kertoo siitä, että Elore on saavuttanut lukijakuntansa ja perinteen- ja kulttuurien tutki-

mus voivat hyvin. Kiitän toimituskuntaa hyvästä yhteistyöstä ja toivon lukijoille nautinnollisia lukuhetkiä - olkaahan Eloreen yhteydessä jatkossakin!

\section{LÄHTEET}

KUUSELA, KIMMO 2005: Open access ja tieteellisen julkaisemisen avoimuus. - Acatiimi 8(3): 26-27. 